\title{
PERLINDUNGAN HUKUM PENGGUNA JASA ELECTRONIC BANKING (E-BANKING) DI TINJAU DARI PERSPEKTIF HUKUM PIDANA DI INDONESIA
}

\author{
Aryani Witasari, Aris Setiono \\ Dosen Fakultas Hukum UNISSULA \\ aryani@unissula.co.id
}

\begin{abstract}
Crime e-banking frequent one ATM card forgery. The perpetrators made a complete fake ATM cards with a magnetic stripe that already contains data records of card fraud. In addition to falsify the card, the perpetrators also know the PIN number of the card is duplicated / forged. ATM card forgery or duplication can be done because the necessary equipment to do so can be easily obtained in the market. This study uses normative legal approach by researching library materials or secondary data only, which relates to the legal protection of e-banking customers in the perspective of criminal law, using the approach of legislation, conceptual and historical. The study says that the legal protection given to customers when there is a loss in e-banking transactions are bank provides its customers the facility if the losses caused by the e-banking, the bank facilitates its customers by providing legal assistance in litigation and non-litigation. 2) The legal protection of the victims of the features of e-banking in the standpoint of criminal law, is shared by the two concepts, namely the protection of the law implicitly and explicitly, of the concept of legal protection that customers have the force of law if the victim of the implications that exist within an e -banking.
\end{abstract}

Keywords: Legal Protection, Customer E-Banking, Criminal Law.

\begin{abstract}
Abstrak
Kejahatan e-banking yang sering terjadi salah satunya pemalsuan kartu ATM. Pelaku kejahatan membuat kartu ATM palsu lengkap dengan magnetic stripe yang sudah berisi rekaman data dari kartu yang dipalsukan. Selain memalsukan kartu, pelaku kejahatan juga mengetahui nomor PIN dari kartu yang digandakan/dipalsukan. Pemalsuan atau penggandaan kartu ATM dapat dilakukan karena peralatan yang diperlukan untuk melakukan hal tersebut dapat diperoleh dengan mudah dipasaran. Penelitian ini menggunakan metode pendekatan hukum normatif dengan meneliti bahan pustaka atau data sekunder saja, yang berhubungan dengan perlindungan hukum nasabah e-banking dalam perspektif hukum pidana, dengan menggunakan pendekatan perundang-undangan, konseptual dan historis. Hasil penelitian menyebutkan bahwa Perlindungan hukum yang diberikan kepada nasabah apabila terjadi kerugian dalam transaksi e-banking adalah bank memberikan fasilitas apabila nasabahnya mengalami kerugian yang disebabkan oleh e-banking, bank memfasilitasi nasabahnya dengan cara memberikan bantuan hukum, baik dalam litigasi maupun non litigasi. 2) Perlindungan hukum terhadap korban dari fitur e-banking dalam sudut pandang hukum pidana, di bagi atas dua konsep yaitu perlindungan hukum secara implisit dan eksplisit, dari kedua konsep perlindungan hukum tersebut nasabah mempunyai kekuatan hukum apabila menjadi korban dari implikasi yang ada didalam fitur e-banking.
\end{abstract}

Kata kunci: Perlindungan Hukum, Nasabah E-Banking, Hukum Pidana. 


\section{A. PENDAHULUAN}

Seiring dengan perkembangan teknologi yang merambah di Negara Indonesia, masyarakat dituntut untuk mengikuti segala perkembangan yang ada baik dari timur maupun barat, secara keseluruhan masyarakat harus menerima segala apa yang ada, dan masuk di Negara Indonesia. Dalam hal ini perkembangan dunia perbankan yang cukup maju dengan ditandai adanya beberapa bank yang menyediakan jasa-jasa perbankan, di antaranya yaitu electronic banking (e-banking).

Mohamad Hatta mengemukakan bahwa bank adalah sendi kemajuan masyarakat dan sekiranya tidak ada bank maka tidak akan ada kemajuan seperti saat ini. Negara yang tidak mempunyai banyak bank yang baik dan benar adalah negara yang terbelakang. Perusahaan saat ini diharuskan memanfaatkan jasa-jasa perbankan dalam kegiatan usahanya jika ingin maju. ${ }^{1}$

Dalam Pasal 2, 3, dan 4 UndangUndang Nomor 7 Tahun 1992 sebagaimana telah diubah dengan Undang-Undang Nomor 10 Tahun 1998 tentang Perbankan dinyatakan asas, fungsi, dan tujuan dari perbankan. Perbankan di Indonesia bertujuan melaksanakan pembangunan nasional dalam rangka meningkatkan pemerataan, pertumbuhan ekonomi, dan stabilitas nasional ke arah peningkatan rakyat banyak. Sebagai lembaga kepercayaan, bank dituntut untuk selalu memperhatikan kepentingan masyarakat disamping kepentingan bank itu sendiri dalam mengembangkan usahanya. Bank juga harus bermanfaat bagi pembangunan ekonomi nasional sesuai dengan fungsi sebagai Agent Of Development dalam rangka mewujudkan pemerataan, pertumbuhan ekonomi, dan stabilitas. $^{2}$

Bank menyediakan layanan electronic banking atau e-banking untuk memenuhi kebutuhan nasabah akan alternatif media untuk melakukan transaksi perbankan, selain

1 H. Malayu S.P Hasibuan, Dasar - dasar Perbankan, Bumi Aksara, Jakarta 2009, hlm.3.

2 Ibid, HIm.. 5. yang tersedia di kantor cabang dan anjungan tunai mandiri (ATM). Dengan electronic banking, nasabah tidak perlu lagi membuang waktu untuk antri di kantor-kantor bank atau ATM, karena saat ini banyak transaksi perbankan dapat dilakukan di manapun, dan kapanpun dengan mudah dan praktis melalui jaringan elektronik, seperti internet, handphone, dan telepon. Contohnya adalah transfer dana antar rekening maupun antar bank, pembayaran tagihan, pembelian pulsa isi ulang, ataupun pengecekan mutasi dan saldo rekening.

Untuk pengguna jasa e-banking ada beberapa hal yang perlu di perhatikan terkait dengan keamanan transaksi e-banking di antaranya yaitu nasabah jangan pernah memberitahukan User ID dan PIN (Personal Identification Number) kepada orang lain, termasuk kepada petugas dan karyawan bank, nasabah dilarang meminjamkan KeyToken pengaman transaksi kepada orang lain, nasabah jangan mencatat User ID di tempat yang mudah diketahui orang lain, nasabah harus gunakan User ID dan PIN secara hati-hati agar tidak terlihat dan diketahui oleh orang lain, dan pastikan nasabah mengakses alamat situs bank dengan benar serta pahami dengan baik situs bank nasabah.

Di dalam beberapa fitur layanan e-banking mempunyai kelebihan dan kekurangan masing-masing, karena pada dasarnya fitur layanan tersebut hanyalah buatan manusia yang memanfaatkan fasilitas dan kemajuan teknologi dengan demikian tidak akan luput dari kesalahan dengan kata lain tidak sempurna, karena bukan diciptakan oleh Allah SWT. Dalam hal ini apabila diperhatikan dari aspek kekurangannya akan menimbulkan beberapa masalah yang akan dialami oleh pengguna jasa layanan e-banking walaupun sudah diminimalisasikan kemungkinan adanya kekurangan tersebut, sebagai pembawa hak dan kewajiban dengan adanya hubungan hukum antara pihak bank dan nasabah, maka di sini nasabah menuntut perlindungan hukum apabila terjadi masalah yang diakibatkan 
oleh layanan e-banking, serta perlindungan hukum dalam bentuk apa yang diberikan oleh pihak bank kepada nasabah.

Kejahatan di dalam e-banking yaitu kejahatan kartu ATM. Kejahatan kartu ATM yang sering terjadi adalah pemalsuan kartu ATM. Pelaku kejahatan membuat kartu ATM palsu lengkap dengan magnetic stripe yang sudah berisi rekaman data dari kartu yang dipalsukan. Selain memalsukan kartu, pelaku kejahatan juga mengetahui nomor PIN dari kartu yang digandakan/dipalsukan. Pemalsuan atau penggandaan kartu ATM dapat dilakukan karena peralatan yang diperlukan untuk melakukan hal tersebut dapat diperoleh dengan mudah dipasaran. ${ }^{3}$

Modus lainnya dari kejahatan kartu ATM adalah membuat kartu ATM fiktif untuk nomor-nomor rekening nasabah yang tidak menginginkan kartu ATM. Pelaku biasanya menggunakan rekening-rekening nasabah yang saldonya besar namun sudah lama tidak ada aktivitas transaksi. Dengan kartu ATM tersebut maka pelaku dengan leluasa menguras isi rekening nasabah yang tidak aktif tersebut. ${ }^{4}$

Modus kejahatan ATM lainnya adalah terjadi karena kelalaian pemilik kartu ATM. Seorang pemilik kartuATM menuliskan nomor PIN pada kartu ATM yang bersangkutan hingga suatu saat kartu ATM tersebut hilang atau dicuri dan digunakan oleh orang yang menemukan atau yang mencuri kartu tersebut. ${ }^{5}$

Berdasarkan uraian yang dikemukakan diatas, maka dapat dirumuskan beberapa masalah dalam usulan penelitian ini, adalah sebagai berikut:

1. Bagaimana bentuk perlindungan hukum yang diberikan oleh bank kepada nasabah apabilia terjadi kerugian dalam transaksi e-banking ?

2. Bagaimana perlindungan hukum pengguna jasa e-banking dalam perspektif hukum pidana?

3 Tb. Irman S, Anatomi Kejahatan Perbankan (Banking Crime Anatomy), MQS Publhising \& Analisis Grup, hlm. 194.

4 Ibid.

5 Ibid, hlm. 195.

\section{B. METODE PENELITIAN}

Metode penelitian yang dipakai dalam penelitian ini menggunakan metode Penelitian hukum normatif yang mendasarkan hukum sebagai norma dengan metodenya bersifat doktrinal. Sedangkan penelitian hukum empiris memiliki maksud untuk mempelajari saja dan bukan mengajarkan suatu doktrin, sehingga metodenya bersifat non-doktrinal.

Dalam penelitian hukum normatif, penelitian dilakukan dengan cara meneliti bahan pustaka atau data sekunder saja, sedangkan dalam penelitian hukum sosiologis penelitian dilakukan dengan meneliti data primer yang diperoleh langsung dari masyarakat (data dasar). ${ }^{6}$

\section{HASIL PENELITIAN DAN PEMBAHASAN}

1. Bentuk Perlindungan Hukum Yang Diberikan Oleh Bank Kepada Nasabah Apabilia Terjadi Kerugian Dalam Transaksi E-Banking

Berdasarkan Pasal 3 UndangUndang Nomor 11 Tahun 2008 Tentang Informasi dan Transaksi Elektronik menyatakan bahwa :"Pemanfaatan Teknologi Informasi dan Transaksi Elektronik dilaksanakan berdasarkan asas kepastian hukum, manfaat, kehatihatian, itikad baik, dan kebebasan memilih teknologi atau netral teknologi.Sedangkan berdasarkan Pasal 4 Undang-Undang Nomor 11 Tahun 2008 Tentang Informasi dan Transaksi Elektronik, Pemanfaatan Teknologi Informasi dan Transaksi Elektronik dilaksanakan dengan tujuan untuk:

a. Mencerdaskan kehidupan bangsa sebagai bagian dari masyarakat informasi dunia;

b. Mengembangkan perdagangan dan perekonomian nasional dalam rangka meningkatkan kesejahteraan masyarakat;

c. Meningkatkan efektivitas dan efisiensi pelayanan publik;

d. Membuka kesempatan seluas-luasnya kepada setiap orang untuk memajukan pemikiran dan kemampuan di bidang penggunaan dan pemanfaatan Teknologi

6 Ibid, hlm. 12-14. 
Informasi seoptimal mungkin dan bertanggung jawab; dan

e. Memberikan rasa aman, keadilan, dan kepastian hukum bagi pengguna dan penyelenggara Teknologi Informasi.

Pada Undang-Undang Nomor 10 Tahun 1998 perubahan atas UndangUndang Nomor 7 Tahun 1992 Tentang Perbankan pasal 29 ayat (4) yang menyatakan bahwa :

"Untuk kepentingan nasabah, bank wajib menyediakan informasi mengenai kemungkinan timbulnya risiko kerugian sehubungan dengan transaksi nasabah yang dilakukan melalui bank."

Berdasarkan Peraturan Bank Indonesia Nomor 9/15/PBI/2007 Tentang Penerapan Manajemen Risiko Dalam Penggunaan Teknologi Informasi Oleh Bank Umum tercantum dalam.pasal 1 ayat (3) yang menyatakan bahwa : "Layanan perbankan melalui media elektronik atau selanjutnya disebut Electronic Banking adalah layanan yang memungkinkan nasabah bank untuk memperoleh informasi, melakukan komunikasi, dan melakukan transaksi perbankan melalui media elektronik antara lain ATM, phone banking, electronic fund transfer, internet banking, mobile phone."

Selain itu tercantum dalam pasal 1 ayat (7) yang menyatakan bahwa disaster recovery center (DRC) adalah fasilitas pengganti pada saat Pusat Data (data center) mengalami gangguan atau tidak dapat berfungsi antara lain karena tidak adanya aliran listrik ke ruang komputer, kebakaran, ledakan atau kerusakan pada komputer, yang digunakan sementara waktu selama dilakukannya pemulihan pusat data bank untuk menjaga kelangsungan kegiatan usaha (business continuity).

Dasar hukum mengenai transaksi electronic banking khususnya bagi kegiatan perbankan belum ada undang-undang secara khusus yang mengaturnya, namun ketentuan-ketentuan berupa peraturan dan Surat Edaran
Bank Indonesia sebagaimana yang telah diuraikan diatas dapat digunakan sebagai dasar hukum transaksi electronic banking

Perlindungan hukum seorang nasabah pengguna jasa e-banking dalam hal ini mendapatkan perlindungan hukum berdasarkan ketentuan hukum positif yang mengatur, baik permasalahan dalam perspektif hukum perdata, maupun permasalahan dalam perspektif hukum pidana. Perlindungan hukum dalam perspektif hukum pidana yaitu berdasarkan ketentuan yang diatur didalam Undang-undang No. 8 Tahun 1981 tentang Kitab Undang-undang Hukum Pidana. Seorang nasabah yang menjadi korban atas jasa e-banking dapat menyelesaikannya melalui dua cara yaitu litigasi dan non litigasi, dan membayar ganti rugi atau memulihkan kredibilitas nasabah, dalam hal ini dipilih berdasarkan masalah/kasus yang dialaminya.

Bank memberikan bentuk perlindungan hukum terhadap nasabah dengan cara memberikan fasilitas, apabila nasabahnya mengalami kerugian yang disebabkan oleh e-banking, bank memfasilitasi nasabahnya dengan cara memberikan bantuan hukum, baik dalam litigasi maupun non litigasi, hal ini bertujuan semata-mata dalam perspektif perlindungan hukum terhadap nasabah dan tercapainya keadilan, kemanfaatan serta kepastian hukum.

Dalam hal ini penulis akan memaparkan beberapa contoh kasus yang sering terjadi dan sering di alami oleh nasabah yang menggunakan layanan electronik bank, di antaranya yaitu :

1. Kasus e-banking, misalnya : pada pengguna ATM, transaksi sudah berhasil dilakukan, akan tetapi uang tidak keluar.

Dalam hal ini dengan menggunakan pendekatan teori hukum alam, yang meletakan keadilan sebagai tujuan utama hukum maka jika terjadi kasus diatas maka seharusnya bank 
memberikan ganti rugi dalam bentuk jumlah saldo yang telah digunakan sebagai pembayaran.

2. Kasus Internet Banking, nasabah melakukan transfer dan saldo telah berkurang, tetapi uang yang ditransfer tidak diterima pada pihak yang di transfer oleh nasabah.

Dalam hal ini dengan menggunakan pendekatan teori hukum alam, yang meletakan keadilan sebagai tujuan utama hukum maka jika terjadi kasus diatas maka seharusnya bank memberikan ganti rugi dalam bentuk jumlah saldo yang telah digunakan sebagai pembayaran.

3. Bagaimana jika seorang nasabah melakukan transaksi pembayaran listrik, telepon, tagihan air, dan seterusnya ternyata dikemudian hari oleh pihak PLN dinyatakan bahwa nasabah tersebut dianggap belum pernah membayar dan nasabah mendapatkan sanksi pemutusan listrik dan harus membayar denda. Dalam hal ini dengan menggunakan pendekatan teori hukum alam, dalam kasus diatas bank mampu menyelesaikan kasus tersebut dengan cara mencari penyebab yang terjadinya, karena dalam kasus diatas terdapat dua teknis yang tidak sinkron dengan jaringan yang ada pada layanan-layanan pembayaran, dengan demikian bank akan tahu penyebab terjadinya permasalahan tersebut dan bank bisa memilih cara penyelesaianya serta perlindungan hukum terhadap nasabahnya.

Perlindungan nasabah merupakan permasalahan yang sampai saat ini belum mendapat tempat yang baik dalam sistem perbankan nasional. Berdasarkan Pasal 26 ayat (2) Undang - undang Nomor. 11 Tahun 2008 tentang ITE, menyatakan bahwa, setiap orang yang dilanggar haknya sebagaimana dimaksud pada ayat (1) dapat mengajukan gugatan atas kerugian yang ditimbulkan berdasarkan
Undang-undang ini. Artinya dalam hal ini seorang nasabah wajib dan sah secara hukum mendapatkan perlindungan hukum, apabila terjadi masalah dalam hubungan antara pihak perbankan dan nasabah dalam menggunakan layanan electronik bank, seorang nasabah yang mengalami kerugian akibat layanan electronik bank, dapat mengajukan gugatan kepada pihak bank untuk meminta ganti rugi terhdap kerugian yang dialaminya hal ini tertuang dalam Pasal 26 ayat (2) Undang-undang Nomor 11 Tahun 2008 tentang ITE, dengan demikian secara peraturan perundang-undangan bahwa seorang nasabah di lindungi oleh hukum yang terkait.

Undang-undang No. 11 tahun 2008 tentang ITE telah menjadi payung hukum bagi penyelenggaraan kegiatan transaksi elektronik, yang diselenggarakan oleh bank. Undang-Undang ITE telah mengatur mengenai tanggung jawab yang fair antara penyelenggara sistem elektronik bank dan nasabah.

Memenuhi prinsip hubungan keperdataan nasabah dengan bank, maka bank bertanggung jawab terhadap pelaksanaan penyelenggaraan teknologi informasi yang menggunakan jasa pihak penyedia jasa. Demikian pula pihak penyelenggara jasa tersebut akan terikat dengan segala ketentuan sebagai pihak terkait bank.

\section{Perlindungan Hukum Korban Pengguna Jasa E-Banking Dalam Perspektif Hukum Pidana.}

Berdasarkan Pasal 26 ayat (2) Undang-undang Nomor 11 Tahun 2008 tentang ITE, menyatakan bahwa, setiap orang yang dilanggar haknya sebagaimana dimaksud pada ayat (1) dapat mengajukan gugatan atas kerugian yang ditimbulkan berdasarkan Undangundang ini.

Adapun beberapa perbuatan yang di larang dalam Undang-undang Nomor 11 Tahun 2008 diantaranya yaitu: 


\section{Pasal 27}

(1) Setiap Orang dengan sengaja dan tanpa hak mendistribusikan dan/atau mentransmisikan dan/ atau membuat dapat diaksesnya Informasi Elektronik dan/atau Dokumen Elektronik yang memiliki muatan yang melanggar kesusilaan.

(2) Setiap Orang dengan sengaja dan tanpa hak mendistribusikan dan/atau mentransmisikan dan/ atau membuat dapat diaksesnya Informasi Elektronik dan/atau Dokumen Elektronik yang memiliki muatan perjudian.

(3) Setiap Orang dengan sengaja dan tanpa hak mendistribusikan dan/atau mentransmisikan dan/ atau membuat dapat diaksesnya Informasi Elektronik dan/atau Dokumen Elektronik yang memiliki muatan penghinaan dan/atau pencemaran nama baik.

(4) Setiap Orang dengan sengaja dan tanpa hak mendistribusikan dan/atau mentransmisikan dan/ atau membuat dapat diaksesnya Informasi Elektronik dan/atau Dokumen Elektronik yang memiliki muatan pemerasan dan/atau pengancaman.

\section{Pasal 28}

(1) Setiap Orang dengan sengaja dan tanpa hak menyebarkan berita bohong dan menyesatkan yang mengakibatkan kerugian konsumen dalam Transaksi Elektronik.

(2) Setiap Orang dengan sengaja dan tanpa hak menyebarkan informasi yang ditujukan untuk menimbulkan rasa kebencian atau permusuhan individu dan/ atau kelompok masyarakat tertentu berdasarkan atas suku, agama, ras, dan antargolongan (SARA).

Pasal 29

Setiap Orang dengan sengaja dan tanpa hak mengirimkan Informasi Elektronik dan/atau Dokumen Elektronik yang berisi ancaman kekerasan atau menakut-nakuti yang ditujukan secara pribadi.

\section{Pasal 30}

(1) Setiap Orang dengan sengaja dan tanpa hak atau melawan hukum mengakses Komputer dan/atau Sistem Elektronik milik Orang lain dengan cara apa pun.

(2) Setiap Orang dengan sengaja dan tanpa hak atau melawan hukum mengakses Komputer dan/atau Sistem Elektronik dengan cara apa pun dengan tujuan untuk memperoleh Informasi Elektronik dan/atau Dokumen Elektronik.

(3) Setiap Orang dengan sengaja dan tanpa hak atau melawan hukum mengakses Komputer dan/atau Sistem Elektronik dengan cara apa pun dengan melanggar, menerobos, melampaui, atau menjebol sistem pengamanan.

\section{Pasal 31}

(1) Setiap Orang dengan sengaja dan tanpa hak atau melawan hukum melakukan intersepsi atau penyadapan atas Informasi Elektronik dan/atau Dokumen Elektronik dalam suatu Komputer dan/atau Sistem Elektronik tertentu milik Orang lain.

(2) Setiap Orang dengan sengaja dan tanpa hak atau melawan hukum melakukan intersepsi atas transmisi Informasi Elektronik dan/ atau Dokumen Elektronik yang tidak bersifat publik dari, ke, dan di dalam suatu Komputer dan/ atau Sistem Elektronik tertentu milik Orang lain, baik yang tidak menyebabkan perubahan apa pun maupun yang menyebabkan adanya perubahan, penghilangan, dan/atau penghentian Informasi Elektronik dan/atau Dokumen Elektronik yang 
sedang ditransmisikan.

(3) Kecuali intersepsi sebagaimana dimaksud pada ayat (1) dan ayat (2), intersepsi yang dilakukan dalam rangka penegakan hukum atas permintaan kepolisian, kejaksaan, dan/atau institusi penegak hukum lainnya yang ditetapkan berdasarkan undang-undang.

(4) Ketentuan lebih lanjut mengenai tata cara intersepsi sebagaimana dimaksud pada ayat (3) diatur dengan Peraturan Pemerintah.

\section{Pasal 32}

(1) Setiap Orang dengan sengaja dan tanpa hak atau melawan hukum dengan cara apa pun mengubah, menambah, mengurangi, melakukan transmisi, merusak, menghilangkan, memindahkan, menyembunyikan suatu Informasi Elektronik dan/atau Dokumen Elektronik milik Orang lain atau milik publik.

(2) Setiap Orang dengan sengaja dan tanpa hak atau melawan hukum dengan cara apa pun memindahkan atau mentransfer Informasi Elektronik dan/atau Dokumen Elektronik kepada Sistem Elektronik Orang lain yang tidak berhak.

(3) Terhadap perbuatan sebagaimana dimaksud pada ayat (1) yang mengakibatkan terbukanya suatu Informasi Elektronik dan/atau Dokumen Elektronik yang bersifat rahasia menjadi dapat diakses oleh publik dengan keutuhan data yang tidak sebagaimana mestinya.

\section{Pasal 33}

Setiap Orang dengan sengaja dan tanpa hak atau melawan hukum melakukan tindakan apa pun yang berakibat terganggunya Sistem Elektronik dan/ atau mengakibatkan Sistem Elektronik menjadi tidak bekerja sebagaimana mestinya.
Jadi Pasal-pasal diatas menguraikan beberapa delik tindak pidana didalam Undang-undang No 11 Tahun 2008 tentang ITE, ini merupakan lex specialis dari KUHP, undang-undang tersebut bertujuan melengkapi dari KUHP, jadi apabila perbuatan tersebut tidak diatur didalam KUHP, maka undang-undang tersebut dapat diterapkan.

Apabila berbicara tentang korban tentunya tidak terlepas dari suatu peristiwa yang mengakibatkan timbulnya suatu penderitaan dan kerugian, karena pada dasarnya penderitaan dan kerugian dalam suatu peristiwa inilah yang menjadi makna arti korban. Mengenai penderitaan dan kerugian setiap korban tentunya berbeda-beda dan tergantung peristiwa yang dialaminya. Terkait pembicaraan tentang korban inilah yang selalu menjadi pembahasan bagi suatu bidang ilmu yaitu "victimologi".

Secara terminologi, victimologi berarti suatu studi yang mempelajari tentang korban, penyebab timbulnya korban dan akibat-akibat penimbulan korban yang merupakan masalah manusia sebagai suatu kenyataan sosial. ${ }^{8}$ Yang dimaksud perlindungan korban kejahatan ialah: upaya-upaya perlindungan terhadap bentuk viktimisasi yang dapat menjadi sebab adanya penderitaan mental, fisik, dan sosial pada seseorang. Selain itu, perlindungan kepada korban juga berarti, suatu upaya hukum untuk melindungi korban sehingga korban dapat melaksanakan hak dan kewajibannya dengan seimbang dan manusiawi. ${ }^{9}$

Dalam rangka pengaturan konsep perlindungan terhadap korban kejahatan, maka sangat perlu diperhatikan tentang esensi kerugian yang diderita si korban.

7 Mahesa Jati Kusuma, Hukum Perlindungan Nasabah Bank : Upaya Hukum Melindungi Nasabah Bank Terhadap Tindak Kejahatan ITE di Bidang Perbankan, Nusamedia, hlm. 31.

8 Paulus Hadisuprapto, Victimolgi : Perkembangan Konsep dan Kajiannya", Pascasarjana IImu Hukum Universitas Diponegoro, Semarang 2007, hlm. 152.

9 Ibid. 
Esensi kerugian tersebut tidak hanya bersifat material atau penderitaan fisik saja melainkan juga yang bersifat psikologis ${ }^{10}$. Dalam hal konsep perlindungan terhadap korban kejahatan disamping langkahlangkah yuridis dapat juga diiringi dengan langkah-langkah non yuridis dalam bentuk pencegahan.

Menurut Barda Nawawi Arief, pengertian "perlindungan korban" dapat dilihat dari dua makna, yaitu :11

a. Dapat diartikan sebagai "perlindungan hukum untuk tidak menjadi korban tindak pidana" (berarti perlindungan HAM atau kepentingan hukum seseorang);

b. Dapat diartikan sebagai "perlindungan untuk memperoleh jaminan/santunan hukum atas penderitaan/kerugian yang telah menjadi korban tindak pidana" (jadi identik dengan "penyantunan korban"). Bentuk santunan itu dapat berupa pemulihan nama baik (rehabilitasi), pemulihan keseimbangan batin (antara lain, dengan permaafan), pemberiaan ganti rugi (restitusi, kompensasi, jaminan/santunan kesejahteraan sosial), dan sebagainya.

Undang-undang No. 10 Tahun 1998 tentang Perbankan merupakan penyempurnaan dari Undang-undang No. 7 Tahun 1992, perubahan tersebut antara lain didasarkan atas pertimbangan perlunya perundang-undangan dibidang perbankan yang mampu menjangkau perkembangan perekonomian nasional maupun internasional yang senantiasa bergerak cepat disertai dengan tantangan yang semakin luas. Teknologi informasi dan elektronik telah mengubah perilaku dan pola hidup masyarakat secara global. Sejalan dengan itu, teknologi informasi saat ini menjadi pedang bermata dua,

10 Muladi dan Barda Nawawi Arief, Bunga Rampai Hukum Pidana, PT. Kencana Media Grup, hlm. 79.

11 Barda Nawawi Arief, Masalah Penegakan Hukum dan Kebijakan Hukum Pidana dalam Penanggulangan Kejahatan, PT. Kencana Media Grup, hlm. 61. karena selain memberikan konstribusi pada peningkatan kesejahteraan, dan kemajuan peradaban manusia, sekaligus juga menjadi saran efektif untuk melakukan perbuatan melawan hukum. ${ }^{12}$

Korban kejahatan e-banking, pada umumnya adalah mereka yang secara langsung maupun tidak langsung terlibat dalam sebuah proses yang memanfaatkan sistem teknologi telematika. Semakin dekat keterlibatannya dengan proses pemanfaatan teknologi, semakin besar potensinya untuk menjadi korban kejahatan e-banking.

Kejahatan perbankan melalui kecanggihan ITE tidak hanya berskala nasional, tetapi juga berskala regional dan internasional. Lebih jauh dilihat dari aspek korbannya, kriminalitas perbankan bertendensi besar dan masal dimana pelaku umumnya intelektual yang sulit tersentuh oleh perangkat-perangkat hukum. ${ }^{13}$

Subjek korban kejahatan perbankan terdiri dari: (1) orang dalam, yakni para anggota Direksi, anggota Komisaris, pegawai bank atau pemegang sham ; (2) nasabah bank, yakni nasabah penyimpan, nasabah debitor atau nasabah yang menggunakan jasa bank selain jasa simpanan dan kredit; (3) pihak ketiga, yakni orang atau korporasi yang bukan orang lain dalam ataupun nasabah bank.

Didasarkan pada elemen karakteristik dasar diatas, maka tindak pidana perbankan dapat digolongkan dalam 3 (tiga) klasifikasi sebagai berikut : 1. Tindak pidana perbankan dilakukan oleh bank yang mengganggu dan membahayakan sistem moneter;

2. Tindak pidana perbankan yang dilakukan oleh bank yang menggangu

12 Ahmad M. Romli, Pager Gunung, Indra Apriadi, Menuju Kepastian Hukum Di Bidang Informasi dan Transaksi Elektronik, Departemen Komunikasi dan Informasi RI, Jakarta 2005, hlm. 132.

13 N.H.T Siahaan, Pencucian Uang dan Kejahatan Perbankan, Jakarta Penerbit Pustaka Sinar Harapan, 2005, hlm. 157. 
atau membahayakan sistem pembayaran.

3. Tindak pidana perbankan yang dilakukan oleh seorang atau suatu lembaga terhadap suatu bank yang membahayakan kelangsungan hidup bank tersebut. ${ }^{14}$

Perusahaan perbankan dapat melakukan perlindungan dan proteksi terhadap para nasabahnya. Sebagai contoh nyata, Barclays Bank berupaya untuk melindungi nasabahnya agar tidak menjadi korban kejahatan terhadap e-banking. Apabila nasabah yang akan melakukan transaksi menggunakan e-banking dengan cara mentransfer uang yang jumlahnya sangat besar kepada rekening eksternal, mereka harus menelepon terlebih dahulu bank bersangkutan untuk menginisiasi transaksi tersebut.

Selain mengambil kebijakan pembatasan jumlah dana yang dapat ditransfer sebagaimana diatas, pihak bank dalam hal ini mengambil kebijakan bahwa apabila para nasabah bank yang dimaksud melakukan transfer rutin (menggunakan fitur e-banking) kepada pihak-pihak yang di tujuan baik perseorangan maupun korporasi. Artinya bukan sebagai suatu bill payment biasa, nasabah tersebut harus terlebih dahulu menukar uang yang akan ditransfer itu lebih dari nominal yang ditentukan oleh pihak perbankan. Dengan cara demikian, bank dapat membantu menghindarkan nasabah dari kemungkinan terjerumus menjadi korban dari fitur e-banking.

Berkaitan dengan perlindungan hukum terhadap nasabah yang menjadi korban kejahatan atas penyalahgunaan e-banking, sistem perbankan di Indonesia melakukan perlindungan hukum terhadap nasabah yang menjadi korban kejahatan, di antaranya yaitu :

14 Reni Syahjdeni, Tindak Pidana Perbankan; Cours Material pada pasca sarjana IImu Hukum Universitas Indonesia, Jakarta UI, 2000, hlm.37.
1. Perlindungan secara implisit, (Implisit Deposit Protection).

Yaitu perlindungan yang dihasilkan oleh pengawasan dan pembinaan yang efektif, yang dapat menghindarkan terjadinya kebangkrutan bank. Perlindungan ini diperoleh melalui:

a) Peraturan perundang-undangan dibidang perbankan,

b) Perlindungan yang dihasilkan oleh pengawas dan pembinaan yang efektif, yang dilakukan oleh Bank Indonesia,

c) Upaya menjaga kelangsungan usaha bank sebagailembaga pada khususnya, dan perlindungan terhadap sistem perbankan pada umumnya,

d) memelihara tingkat kesehatan bank,

e) melakukan usaha sesuai dengan prinsip kehatia-hatian,

f) cara pemberian kredit yang tidak merugikan bank dan kepentingan nasabah, dan

g) menyediakan informasi resiko pada nasabah.

2. Perlindungan secara eksplisit, (Eksplisit Deposit Protection)

Yaitu perlindungan melalui pembentukan suatu lembaga yan menjamin simpanan masyarkat, sehingga apabila bank mengalami kegagalan, lembaga tersebut akan mengganti dana masyarakat yang disimpan pada bank yang gagal tersebut. Perlindungan ini diperoleh melalui pembentukan lembaga yang menjamin simpanan masyarakat, sebagaimana yang diatur dalam Keputusan Presiden RI No. 26 Tahun 1998 tentang Jaminan Terhadap Kewajiban Bank Umum.

Selanjutnya, dalam membahas mengenai perlindungan hukum bagi nasabah pengguna jasa e-banking dalam konsep hukum pidana, setidaknya dapat disimpulkan bahwa hakikat dari perlindungan hukum tersebut adalah 
melindungi kepentingan nasabah penyimpanan dan simpanannya dalam sebuah bank, serta resiko kerugian yang menimpanya. Perlindungan hukum ini juga merupakan upaya untuk mempertahankan dan memelihara kepercayaan masyarakat khususnya nasabah, maka sudah sepatutnya dunia perbankan perlu memberikan perlindungan hukum kepada nasabah sebagai korban kejahatan e-banking.

Perlindungan hukum pengguna jasa e-banking bersadarkan teori hukum alam atau hukum moral sebagai pijakannya. Dalam ajaran moral biasanya diwujudkan dengan doktrin: jangan mencuri atau jangan mengambil apa yang bukan milikmu. Doktrin ini menurut penulis diadopsi untuk memberikan perlindungan hukum pengguna jasa e-banking agar hak-haknya tidak dilanggar orang lain dan tetap mendapatkan perlindungan hukum dengan sebagaimana mestinya. Namun sesungguhnya doktrin hukum alam yang disebutkan tidak adanya melindungi hak-hak pihak lain, termasuk hak masyarakat lokal atau masyarakat tradisional atas penggunaan pengetahuan tradisional mereka

\section{PENUTUP}

\section{Kesimpulan}

Berdasarkan hasil penelitian yang telah dilakukan, penulis menarik kesimpulan bahwa:

1. Perlindungan hukum yang diberikan oleh pihak bank kepada nasabah apabila terjadi kerugian dalam transaksi e-banking adalah bank memberikan fasilitas apabila nasabahnya mengalami kerugian yang disebabkan oleh e-banking, bank memfasilitasi nasabahnya dengan cara memberikan bantuan hukum, baik dalam litigasi maupun non litigasi. Dalam proses litigasi nasabah berhak mengajukan gugatan atas kasus yang dialaminya, dan dalam proses non litigasi nasabah diberikan fasilitas untuk menyelesaikan kasus ini melalu metode alternative penyelesaian sengketa, atau biasa dikenal dengan alternative dispute resolution, hal ini bertujuan semata-mata dalam perspektif perlindungan hukum terhadap nasabah dan tercapainya keadilan, kemanfaatan serta kepastian hukum.

2. Perlindungan hukum terhadap korban dari fitur e-banking dalam sudut pandang hukum pidana, yaitu di bagi atas dua konsep perlindungan hukum diantaranya perlindungan hukum secara implisit dan perlindungan hukum secara eksplisit, dari kedua konsep perlindungan hukum tersebut nasabah mempunyai kekuatan hukum apbila menjadi korban dari implikasi yang ada didalam fitur e-banking, di dalam regulasinya nasabah dilindungi langsung oleh dua unsur yaitu dari Undang-undang perbankan dan dari unsur pengawas bank yaitu dalam hal ini Bank Indonesia selaku pengawas dari bank yang ada di Indonesia khususnya yang menyediakan fitur layanan e-banking.

\section{Saran}

1. Agar dibuat peraturan perundangundangan yang lengkap dan up to date sesuai dengan kemajuan teknologi informasi yang mengatur secara jelas dan tegas mengenai hak dan kewajiban pihak bank dan nasabah, terutama agar kemajuan teknologi di bidang informasi ini dapat menjamin rasa aman dan nyaman bagi para pihak serta menghindarkan dari kerugian bagi para nasabah.

2. Seyogyanya untuk mengatasi permasalahan perlindungan 
hukum seorang nasabah e-banking dalam perspektif hukum pidana, perbankan dalam hal ini pihak bank mampu memberikan fasilitas untuk memfasilitasi nasabah yang menjadi korban dari kejahatan perbankan melalui kerja sama dengan pihak-pihak terkait didalam sistem peradilan pidana, dan memberikan perlindungan hukum serta bantuan hukum langsung yang difasilitasi oleh pihak perbankan, dengan tujuan mempermudah dalam proses penyelesaian kasus tersebut.

\section{DAFTAR PUSTAKA}

\section{- Buku-Buku:}

Ahmad M. Romli, Pager Gunung, Indra Apriadi, Menuju Kepastian Hukum Di Bidang Informasi dan Transaksi Elektronik, Departemen Komunikasi dan Informasi RI, Jakarta 2005.

Barda Nawawi Arief, Masalah Penegakan Hukum dan Kebijakan Hukum Pidana dalam Penanggulangan Kejahatan, PT. Kencana Prenada Media Grup, Jakarta, 2007.

Johanes Ibrahim, Cross Default and Cross Collateral Sebagai upaya menyelesaikan kredit bermasalah, Revika Adiatama Bandung, 2000.

Mahesa Jati Kusuma, Hukum Perlindungan Nasabah Bank: Upaya Hukum Melindungi Nasabah Bank Terhadap Tindak Kejahatan ITE di Bidang Perbankan, Nusamedia, 2005.

Mochtar kusuma atmaja, Fungsi dan Perkembangan Hukum Dalam Pembangunan Nasional, (Lembaga Penelitian Hukum dan Kriminologi”, Fakultas Hukum Universitas Padjadjaran), 2000.

Muladi dan Barda Nawawi Arief, Bunga Rampai Hukum Pidana, PT. Kencana Media Grup, 2010.

N.H.T Siahaan, Pencucian Uang dan Kejahatan Perbankan, Jakarta Penerbit Pustaka Sinar Harapan, 2005.

Paulus Hadisuprapto, Victimolgi: Perkembangan Konsep dan Kajiannya", Pascasarjana Ilmu Hukum Universitas Diponegoro, Semarang 2007.

Reni Syahjdeni, Tindak Pidana Perbankan; Cours Material pada pasca sarjana IImu Hukum Universitas Indonesia, Jakarta UI, 2000.

Ronny Hanitjo Soemitro, Metodologi Penelitian Hukum, Jakarta: Ghalia Indonesia, 1982.

Satjipto Rahardjo, Hukum dan Perubahan Sosial ( Suatu Tinjauan Teoritis Serta PengalamanPengalaman di Indonesia), Yogyakarta : Genta Publishing, 2009.

\section{- Peraturan perundang-undangan:}

Undang-Undang Nomor 31 Tahun 1999 Tentang Pemberantasan Tindak Undang-Undang

Dasar Negara Republik Indonesia (UUD NRI) 1945

Undang-Undang Nomor 11 Tahun 2008 tentang ITE

Undang-Undang Nomor 3 Tahun 2004 tentang Perubahan atas Undang-Undang Nomor 23 Tahun 1999 tentang Bank Indonesia

Undang-Undang Nomor 10 Tahun 1998 tentang Perubahan atas Undang-Undang Nomor 7 Tahun 1992 tentang Perbankan

Undang-Undang Nomor 8 Tahun 1999 tentang Perlindungan konsumen. 


\section{- Website :}

http://www.anggaran.depkeu.go.id/

http://64.203.71.11/kompas-cetak/0603/14/finansial/2503968.html

http://emshi.blogs.friendster.com/emshi_blog/2007/03/ebanking_bertra.htm

http://ebrightnet.blogspot.com/2008/01/pengenalan-dasar-internet.html

www.artikata.com.

http://infokorupsi.com/id/korupsi 